f. med. Genet. (1967). 4, 245.

\title{
Concordance and Discordance of Congenital Heart Disease in 20 Families
}

\author{
B. C. CLARE DAVISON \\ From the Medical Research Council, Population Genetics Research Unit, Old Road, Headington, Oxford
}

\section{Some Genetical and Pathological Considerations}

It is generally accepted that the frequency of congenital heart disease is higher in relatives of patients than in the general population. Estimates both of population frequencies, and of the extent to which these frequencies are exceeded in relatives of those affected, vary considerably. This is not surprising as some authors have reported series diagnosed at birth, while others have reported such series but with follow-up to detect cases unrecognized at birth. Stillbirths were not always included, while cases with congenital heart disease found in association with other malformations, or as part of a syndrome, were sometimes excluded. Finally, a majority of the larger studies had, as their starting points, cases identified at specialist cardiac clinics or in children attending hospital, so that the severe cases determining early death would be underreported in such series. Other problems involved in arriving at realistic and useful frequency estimates of congenital heart disease in communities have recently been reviewed by Hay (1966).

Lamy, de Grouchy, and Schweisguth (1957) starting from 1188 patients with congenital heart disease attending a children's cardiac clinic found that $1.5 \%$ of sibs were affected-a frequency 3.6 times that in sibs of controls. They were unable to give an estimate in which they had confidence in respect of frequency in first cousins. None of the parents of the index patients was affected. Fraser (1958) and Fuhrmann (1961) gave ranges of estimates of frequencies in sibs of $1-3 \%$. Nora and Meyer (1966) investigated the relations, who happened to attend the hospital, of 517 children with congenital heart disease, and found $3.4 \%$ of sibs and $1.8 \%$ of parents to be affected. Neill and Strang (1960) found that almost $13 \%$ of 1000 patients attending a cardiac clinic had one or more relatives affected. Of this number, $3 \%$ only had a

Received April 27, 1967. sib affected, $2 \%$ a parent only, $3.7 \%$ a more distant relative, while $4 \%$ had more than one relative affected.

McKeown, MacMahon, and Parsons (i953), using as a starting point live and stillborn children with congenital heart disease found that $1.8 \%$ of sibs born subsequently were affected. The frequencies of other types of malformations were not increased in sibs. This latter finding is confirmed by Campbell (1965) and Lamy et al. (1957).

Lamy et al. (1957) found that consanguinity was 3.6 times higher in parents of children with congenital heart disease than in controls. The most marked associations of parental consanguinity were with situs inversus, pulmonary valve stenosis, and atrial septal defect. The frequency of consanguinity in the data of McKeown et al. (1953) was so low so that no opinion could be made. The same applies to those of Polani and Campbell (1955) who could find no evidence of an association. There was no increase in consanguinity of parents of children with congenital heart disease in the World Health Organization Congenital Malformations Study (Stevenson, Johnston, Stewart, and Golding, 1966).

Types of Congenital Heart Disease Occurring in Relatives. There is little published information where the anatomical lesion has been confirmed at necropsy, at operation, or by sophisticated clinical investigation in families where two or more members had congenital heart disease. Campbell (1965) has reviewed this subject carefully and in particular has compared his own extensive information with that published by Lamy et al. (1957). Data from both sources indicate that in about $40 \%$ of affected sib pairs the malformations are more or less identical ('concordant') and in Campbell's own experience a further $17 \%$ or so are 'partially concordant', for example one of the sibs had Fallot's tetralogy, and the other pulmonary stenosis or interventricular septal defect. Neill and Strang (1960) in their series found that when congenital heart disease 
recurred in the family then the lesion was concordant in $60 \%$ of cases. It is not possible from the data of Nora and Meyer (1966) to identify concordance or discordance in sibs for specific types of congenital heart disease, but they regarded the malformations as being concordant in three-quarters of all affected pairs of relatives.

The above series had as starting point hospital or clinic cases. In that of McKeown et al. (1953) where the identification was by diagnosis in live or stillbirths there were only five sib pairs where the individual diagnosis was certain in both sibs. In three of these, the malformations were the same (one pair each with patent ductus arteriosus, one pair with transposition of the great vessels, and one with ventricular septal defect).

Congenital Heart Disease in Twins. Campbell (1961) summarized his own experience and those of Uchida and Rowe (1957) and Lamy et al. (1957). These series were unselected apart from the fact that at least one member of a twin pair had congenital heart disease. The accuracy of the zygosity diagnosis varied considerably in the series reviewed. Of the 32 monozygous sets of twins only one member of the pair was affected, and both members were affected in one pair of the 25 dizygous sets.

Ross (1959) ascertained from health agencies 37 pairs of twins of known zygosity, of whom at least one member had congenital heart disease. Both members were affected in 2 of 11 monozygous pairs, and in 2 of 26 dizygous pairs. However the exact anatomical lesion was only known in 9 of these 37 pairs.

All these data are biased in respect of the proportion of the pairs called monozygous, but they indicate a very low concordance rate. They are in marked contrast to the selected series of Fuhrmann (1958), who reviewed all cases previously reported and, excluding the series of Uchida and Rowe (1957), Lamy et al. (1957), and Polani and Campbell (1955) mentioned above, found that both members were affected in 16 of 46 monozygous pairs and 2 of 11 dizygous pairs. This is a very selected series in that so many monozygous pairs were reported, but it is clear that it is the exception rather than the rule for both members of a twin pair to be affected.

\section{Present Investigations}

Recognizing the paucity of good data on concordance and discordance in pairs of close relatives with congenital heart disease, it was decided to scrutinize the available information in the Unit. This came from two sources.

(a) The first was 10 families who had been referred to the Unit either for genetic advice or because a clinical colleague thought that we would be interested in the family.

(b) The second was from studies of families living in Oxfordshire and Berkshire in which from 1960 to 1965 inclusive a child under 5 years of age had died and the primary cause of death as certified was congenital heart disease. From this source 206 families were identified. The certified diagnosis proved incorrect in 7 cases, and in another 15 the congenital heart disease was not further specified and inquiries were not pursued. In 48 , the family was not traced or the child was illegitimate and so the mother was not visited. In the remaining 136, the diagnosis was confirmed from hospital records and the families were investigated. Eleven of these were found to have at least two members with congenital heart disease (in one family both affected were identified as 'propositi').

The two sources of data provided a total of 20 families, each of which contained two or more members who had congenital heart disease. In 14 of these, the exact anatomical lesion was known in the propositus and at least one other relative. There were two sib pairs where the propositus on clinical examination was diagnosed as having congenital heart disease, while in their sibs the malformation had been identified at necropsy. In the remaining four families the diagnosis in the propositi had been made at necropsy, but the exact lesion in their affected relatives was unknown.

Affected Pairs of Sibs. The malformations of affected sib pairs are set out in Table I. Of 10 pairs so identified, 8 had been referred to the Unit for genetic advice. Three were like-sex pairs (2 male/male and 1 female/female) and seven were unlike sex pairs. The lesions were concordant in three pairs (Family Nos. 205, 69, and 4), partially concordant in three (Family Nos. 120, 108, and 134), and discordant in the remaining four pairs. Family No. 205 is of considerable interest in that the affected sibs (IV. 1 and 2) had identical rare malformations and in addition a maternal aunt (III. 5) had died at 1 week with cyanotic congenital heart disease and a maternal female cousin once removed (III. 12) had patent ductus arteriosus (Fig. 1a). The sibs in Family No. 120 were partially concordant for cardiac defect but one had an absent kidney and ureter while the other had an absent spleen. In Family No. 108 the propositus (whose mother had taken Thalidomide early in that pregnancy) had truncus arteriosus and ventricular septal defect in addition to phocomelia and ear abnormalities, while her older brother, who was still alive, had an aortopulmonary window and ventricular septal defect. The defects here are taken to be partially concordant. The sibs in Family No. 209 were discordant for the heart lesion, but both had exomphalos with no other lesion involving the alimentary tract. The 
Concordance and Discordance of Congenital Heart Disease in 20 Families

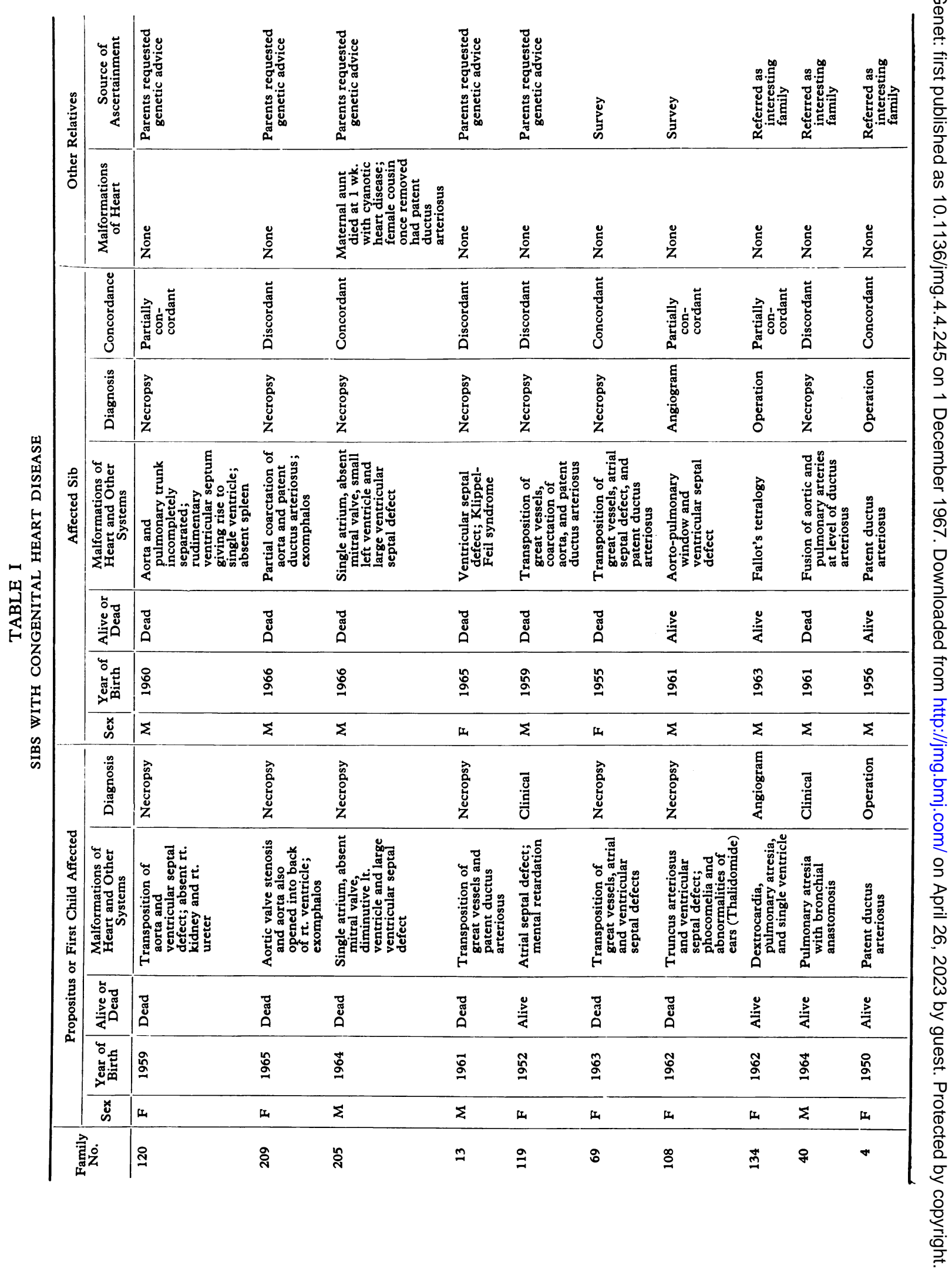


TABLE II

PROPOSITUS AND RELATIVE, OTHER THAN A SIB, AFFECTED WITH CONGENITAL HEART DISEASE

\begin{tabular}{|c|c|c|c|c|c|c|c|c|c|c|c|}
\hline \multirow{2}{*}{$\begin{array}{l}\text { Family } \\
\text { No. }\end{array}$} & \multicolumn{5}{|c|}{ Propositus } & \multicolumn{4}{|c|}{ Affected Relative } & \multirow{2}{*}{$\begin{array}{l}\text { Con- } \\
\text { cordance }\end{array}$} & \multirow{2}{*}{$\begin{array}{c}\text { Source of } \\
\text { Ascertainment }\end{array}$} \\
\hline & Sex & $\begin{array}{c}\text { Year } \\
\text { of } \\
\text { Birth }\end{array}$ & $\begin{array}{l}\text { Alive } \\
\text { or } \\
\text { Dead }\end{array}$ & $\begin{array}{c}\text { Malformations of } \\
\text { Heart and Other } \\
\text { Systems }\end{array}$ & Diagnosis & Sex & Relationship & $\begin{array}{l}\text { Malformation of } \\
\text { Heart }\end{array}$ & $\begin{array}{l}\text { Alive } \\
\text { or } \\
\text { Dead }\end{array}$ & & \\
\hline 33 & $M$ & 1962 & Dead & $\begin{array}{l}\text { Transposition of } \\
\text { great vessels, } \\
\text { coarctation of } \\
\text { aorta, single } \\
\text { ventricle, } \\
\text { dextrocardia, } \\
\text { and situs } \\
\text { inversus }\end{array}$ & Necropsy & $\mathbf{F}$ & $\begin{array}{l}\text { 1st cousin } \\
\text { once } \\
\text { removed }\end{array}$ & Fallot's tetralogy & Alive & $\begin{array}{l}\text { Dis- } \\
\text { cordant }\end{array}$ & Survey \\
\hline $\begin{array}{l}57 \text { and } \\
163\end{array}$ & $M$ & 1963 & Dead & $\begin{array}{l}\text { Septum primum } \\
\text { defect and } \\
\text { persistent lt. } \\
\text { superior vena } \\
\text { cava }\end{array}$ & Necropsy & $M$ & 2 nd cousin & $\begin{array}{l}\text { 'Congenital heart } \\
\text { disease'; } \\
\text { mongolism }\end{array}$ & Dead & Unknown & $\begin{array}{l}\text { Both families } \\
\text { ascertained } \\
\text { indepen- } \\
\text { dently in } \\
\text { survey }\end{array}$ \\
\hline 70 & $M$ & 1964 & Dead & $\begin{array}{l}\text { Single ventricle } \\
\text { and patent } \\
\text { ductus } \\
\text { arteriosus }\end{array}$ & Necropsy & $M$ & 1 st cousin & $\begin{array}{l}\text { Aortic valve } \\
\text { stenosis }\end{array}$ & Alive & $\begin{array}{l}\text { Dis- } \\
\text { cordant }\end{array}$ & Survey \\
\hline 80 & M & 1962 & Dead & $\begin{array}{l}\text { Transposition of } \\
\text { great vessels, } \\
\text { erythroblastosis } \\
\text { foetalis }\end{array}$ & Necropsy & $\mathbf{M}$ & $\begin{array}{l}\text { 1st cousin } \\
\text { once } \\
\text { removed }\end{array}$ & $\begin{array}{l}\text { 'Congenital heart } \\
\text { disease' }\end{array}$ & Alive & Unknown & Survey \\
\hline 95 & $M$ & 1960 & Dead & $\begin{array}{l}\text { Ventricular } \\
\text { septal defect }\end{array}$ & Necropsy & F & $\begin{array}{l}\text { Grand- } \\
\text { mother }\end{array}$ & $\begin{array}{l}\text { Atrial septal } \\
\text { defect }\end{array}$ & Alive & $\begin{array}{l}\text { Dis- } \\
\text { cordant }\end{array}$ & Survey \\
\hline 75 & $\mathbf{F}$ & 1961 & Dead & $\begin{array}{l}\text { Atresia of } \\
\text { pulmonary } \\
\text { valve, atresia of } \\
\text { rt. ventricle, } \\
\text { patent ductus } \\
\text { arteriosus, } \\
\text { ventricular } \\
\text { septal defect }\end{array}$ & Necropsy & $M$ & 1st cousin & Fallot's tetralogy & Dead & $\begin{array}{l}\text { Partially } \\
\text { con- } \\
\text { cordant }\end{array}$ & Survey \\
\hline 97 & $\mathbf{F}$ & 1963 & Dead & $\begin{array}{l}\text { Atrial septal } \\
\text { defect, } \\
\text { mongolism }\end{array}$ & Necropsy & $\mathbf{M}$ & Uncle & $\begin{array}{l}\text { Pulmonary } \\
\text { stenosis }\end{array}$ & Alive & $\begin{array}{l}\text { Dis- } \\
\text { cordant }\end{array}$ & Survey \\
\hline 153 & $\mathbf{F}$ & 1963 & Dead & $\begin{array}{l}\text { Total anomalous } \\
\text { pulmonary } \\
\text { venous } \\
\text { drainage }\end{array}$ & Necropsy & $\begin{array}{l}\mathbf{M} \\
\mathbf{M}\end{array}$ & $\begin{array}{l}\text { 1st cousin } \\
\text { once } \\
\text { removed } \\
\text { (brothers) }\end{array}$ & $\begin{array}{l}\text { 'Congenital heart } \\
\text { disease' }\end{array}$ & $\begin{array}{l}\text { Alive } \\
\text { Alive }\end{array}$ & Unknown & Survey \\
\hline 127 & $M$ & 1961 & Dead & $\begin{array}{l}\text { Large atrial septal } \\
\text { defect giving } \\
\text { rise to a single } \\
\text { atrium }\end{array}$ & Necropsy & $\mathbf{F}$ & Great aunt & $\begin{array}{l}\text { 'Congenital heart } \\
\text { disease' }\end{array}$ & Dead & Unknown & $\begin{array}{l}\text { Parents } \\
\quad \text { requested } \\
\text { genetic } \\
\text { advice }\end{array}$ \\
\hline 122 & $\mathrm{~F}$ & 1965 & Dead & $\begin{array}{l}\text { Truncus } \\
\text { arterious and } \\
\text { cor biloculare }\end{array}$ & Necropsy & M & $\begin{array}{l}\text { 2nd cousin } \\
\begin{array}{l}\text { 1st cousin } \\
\text { once } \\
\text { removed }\end{array}\end{array}$ & $\begin{array}{l}\text { Truncus } \\
\text { arteriousus } \\
\text { and cor } \\
\text { biloculare } \\
\text { Fallot's } \\
\text { tetralogy }\end{array}$ & $\begin{array}{l}\text { Dead } \\
\text { Dead }\end{array}$ & $\begin{array}{l}\text { Con- } \\
\text { cordant }\end{array}$ & $\begin{array}{l}\text { Parents } \\
\text { requested } \\
\text { genetic } \\
\text { advice }\end{array}$ \\
\hline
\end{tabular}

only other non-cardiac malformation was in a child who had Klippel-Feil syndrome, as well as a ventricular septal defect. None of these propositi were twins, and in no case was there any consanguinity of the parents.

Affected Pairs of Relatives other than Sibs. The findings of the 10 families are set out in Table II. All but two of these families were notified from the survey and in one both affected members were ascertained independently. In several in- stances it was not possible to identify the exact anatomical defect in the relatives concerned, but there was no doubt that they were affected and the lesion was discordant in four, unknown in four, partially concordant in one (Family No. 75), and concordant in one (Family No. 122). In the last mentioned, the propositus (IV. 8) and her second cousin (IV. 3) both had truncus arteriosus and cor biloculare, while two other members (III. 4 and III. 17) had Fallot's tetralogy (Fig. 1b). Mongolism was found in two of the propositi and another child 

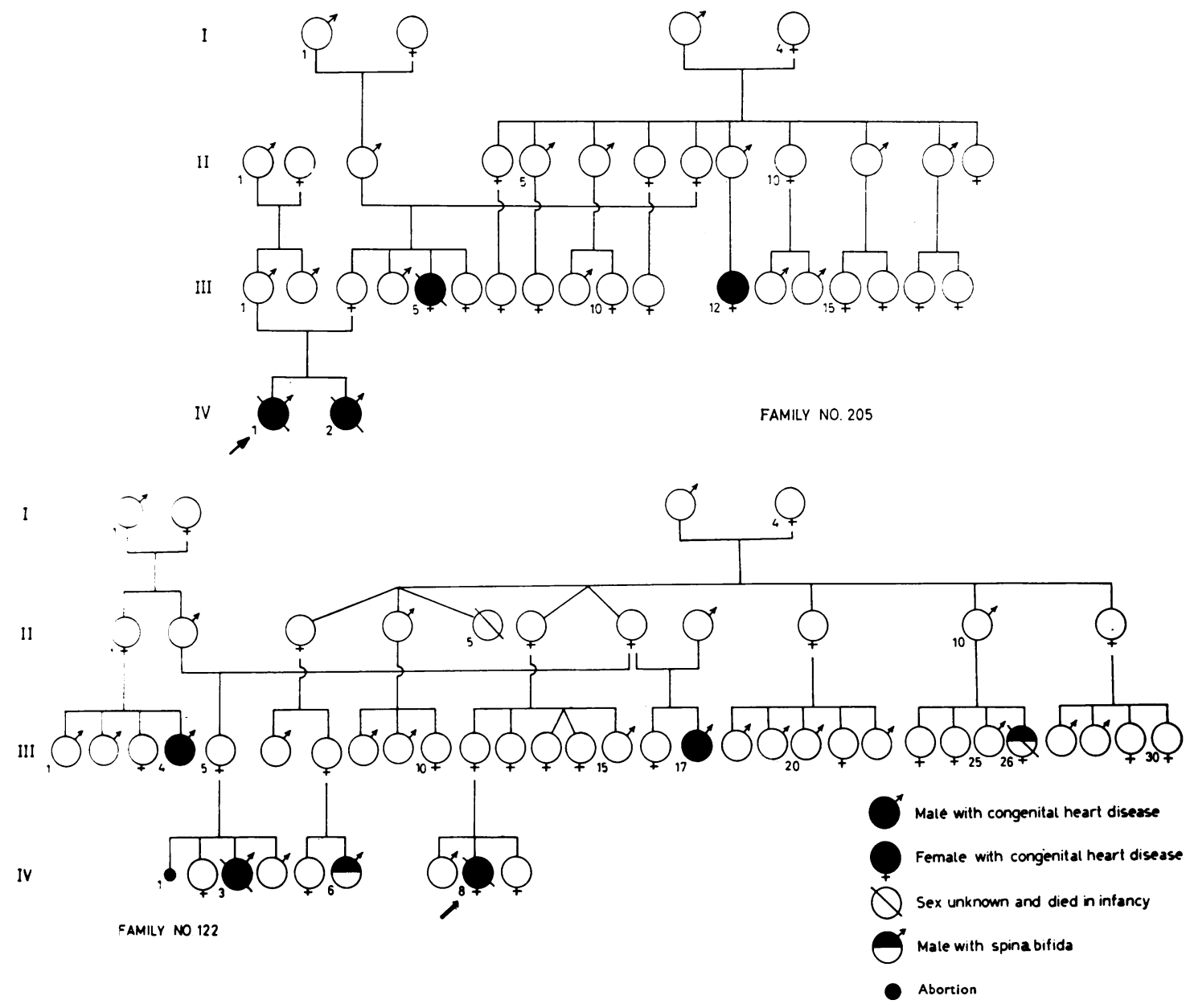

FIg. 1a and b. Pedigrees of 2 families with congenital heart disease.

had rhesus incompatibility. None of these propositi were twins and none of their parents had congenital heart disease.

Non-cardiac Malformations in Relatives of Propositi. There were 6 relatives in 5 of these 20 families who had a congenital malformation other than a cardiac deformity. Neural tube defects were found in 3, cleft lip and palate in 1, oesophageal fistula in 1, and another relative with a 'spinal deformity' had died many years ago. In a further family, posterior congenital cataract was inherited as a dominant, but the exact number of affected relatives was unknown.

\section{Discussion}

Estimates of concordance for congenital heart disease in sibs have varied between 40 and $60 \%$
(Campbell, 1965; Neill and Strang, 1960). Only 10 pairs of sibs have been recorded here, and of these the lesion was concordant in three pairs and partially concordant in another three. Families have been reported where several members had patent ductus arteriosus (e.g. Burman, 1961; Lynch, Grissom, Magnuson, and Krush, 1965), and so it was not surprising to find one such pair of affected sibs. Transposition of the great vessels and the hypoplastic left heart syndrome are uncommon cardiac malformations, but with a high mortality. In one family two sisters were concordant for the former and in another two brothers were concordant for the latter anomaly.

Relatives, other than sibs, known to have congenital heart disease included an uncle, grandmother, two first cousins, and other more distantly related people, and in no case was a parent affected. 
Apart from the family where two members had truncus arteriosus associated with cor biloculare and the one where the proposita had atresia of the pulmonary valve and right ventricle as well as a ventricular septal defect, and her first cousin had Fallot's tetralogy, all the lesions in pairs of relatives were discordant or else unknown. Unfortunately a necropsy was not carried out on the mongol child with clinical evidence of cardiac malformation, but as atrial septal defect is commonly associated with mongolism, it is likely that he and his cousin would have been partially concordant for congenital heart disease.

Since this was a very selected series of cases it is not possible to estimate the frequency of congenital heart disease recurring in sibs and other relatives of the propositi. There did not appear to be any increase in non-cardiac malformations amongst the sibs and other relatives of propositi with congenital heart disease, and this was also found by McKeown et al. (1953), Lamy et al. (1957), and Campbell (1965).

McKusick (1964) considered that subaortic stenosis, supravalvular aortic stenosis, familial cardiomyopathy, and endocardial fibroelastosis were all inherited as single gene traits. Certain syndromes with congenital heart disease as well as other malformations have been shown to be due to segregation of single genes or to chromosomal aberrations. In some families it has been suggested that the cardiac malformation may be inherited as an autosomal dominant but with varying degree of penetrance, for example atrial septal defect (Weil and Allenstein, 1961 ; Howitt, 1961 ; Zuckerman, Zuckerman, Mammen, and Wassermil, 1962). In none of the families reported here was it possible to demonstrate that the cardiac malformations were inherited as single gene traits, but the finding of concordant and partially concordant lesions in sibs makes one suspect that genetic factors can play a major part in causing congenital heart disease.

\section{Summary}

Twenty families where at least one member had congenital heart disease are reported. The lesion was concordant in four pairs of relatives, partially concordant in four, discordant in eight, and unknown in the remainder.

I wish to thank Dr. C. C. Spicer for his help in obtaining the data, and the consultants and general practioners for their co-operation and permission to visit the families. I am most grateful to Dr. Maurice Campbell for his advice on his criteria for concordance and discordance of congenital heart disease. I am indebted to Miss K. Major, S.R.N., H.V., and Miss R. Mason, S.R.N., H.V., who assisted with visiting the families.

\section{REFERENCES}

Burman, D. (1961). Case report. Familial patent ductus arteriosus. Brit. Heart f., 23, 603.

Campbell, M. (1961). Twins and congenital heart disease. Acta genet. (Roma), 10, 443.

- (1965). Causes of malformations of the heart. Brit. med. F., $2,895$.

Fraser, F. C. (1958). Gentic counselling in some common paediatric diseases. Pediat. Clin. N. Amer., 5, 475.

Fuhrmann, W. (1958). Diskordantes Auftreten angeborener Angiokardiopathien bei eineiigen Zwillingen. Z. menschl. Vererb.u Konstit.-lehre, 34, 563.

- (1961). Untersuchungen zur atiologie der angeborenen angiokardiopathien. Acta genet. (Basel), 11, 289.

Hay, J. D. (1966). Population and clinic studies of congenital heart disease in Liverpool. Brit. med. f., 2, 661.

Howitt, G. (1961). Atrial septal defect in 3 generations. Brit. Heart $\mathcal{F}$., 23, 494.

Lamy, M., de Grouchy, J., and Schweisguth, O. (1957). Genetic and non-genetic factors in the etiology of congenital heart disease: a study of 1188 cases. Amer. F. hum. Genet., 9, 17.

Lynch, H. T., Grissom, R. L., Magnuson, C. R., and Krush, A. (1965). Patent ductus arteriosus. Study of two families. $\mathcal{F}$. Amer. med. Ass., 194, 135.

McKeown, T., MacMahon, B., and Parsons, C. G. (1953). The familial incidence of congenital malformation of the heart. Brit. Heart F., 15, 273.

McKusick, V. A. (1964). A genetical review of cardiovascular disease. Circulation, $30,326$.

Neill, C. A., and Strang, R. H. (1960). Family study of congenital heart disease. Amer. F. Dis. Child., 100, 617.

Nora, J. J., and Meyer, T. C. (1966). Familial nature of congenital heart diseases. Pediatrics, 37, 329.

Polani, P. E., and Campbell, M. (1955). An aetiological study of congenital heart disease. Ann. hum. Genet., 19, 209.

Ross, L. J. (1959). Congenital cardiovascular anomalies in twins. Circulation, 20, 327.

Stevenson, A. C., Johnston, H. A., Stewart, M. I. P., and Golding, D. R. (1966). Congenital malformations. A report of a study of series of consecutive births in 24 centres. Bull. Wld Hlth Org., 34, Suppl.

Uchida, I. A., and Rowe, R. D. (1957). Discordant heart anomalies in twins. Amer. F. hum. Genet., 9, 133.

Weil, M. H., and Allenstein, B. J. (1961). A report of congenital heart disease in five members of one family. New Engl. F. Med., 265, 661.

Zuckerman, H. S., Zuckerman, G. H., Mammen, R. E., and Wassermil, M. (1962). Atrial septal defect. Familial occurrence in four generations of one family. Amer. F. Cardiol., 9, 515. 